\title{
Juliano Moreira: the black Brazilian who greatly influenced the modern school of Neurology in Brazil
}

\author{
Juliano Moreira: o brasileiro negro que influenciou profundamente a escola de Neurologia \\ no Brasil \\ Laura Motter ROSSO', Ana Laura da Silva BRANDI', Tais Cristóvão Martins VIEIRA', Edynara Lopes \\ RODRIGUES', Caroline da Silva CAMINHA', Vinicius Farias MAURICIO', Liliane TOUGUINHA', Samuel Masao \\ SUWA 1 , Ingrid Lorena da Silva GOMES², Jonas Alex Morales SAUTE $1,3,4,5,6$
}

\begin{abstract}
Juliano Moreira was a black Brazilian physician, well recognized for his role in the foundation of scientific psychiatry in Brazil; however, little is known about his influences on modern Neurology. Our aim is to highlight Moreira's importance in the field of Neurology and his role in the development of scientific and medical societies in Brazil. We describe his contributions from his doctoral thesis in 1891 to his $27-$ year tenure as the director of the National Hospice for the Insane. We also review Moreira's role in the foundation of societies including the Brazilian Academy of Sciences and the first Brazilian journal dedicated to Neuropsychiatry, concluding that Moreira was one of the most important influential figures for the development of Neurology in Brazil. In addition to his influences on various medical fields, Moreira distinguished himself as an impactful citizen who fought against racist and xenophobic medical theories of his time.
\end{abstract}

Keywords: Juliano Moreira; History of Neurology; School; Neuropsychiatry.

RESUMO

Juliano Moreira foi um médico negro brasileiro reconhecido por seu papel na fundação da psiquiatria científica no Brasil; no entanto, pouco sabemos sobre sua influência na Neurologia moderna no país. Nosso objetivo é destacar a importância de Moreira no campo da Neurologia e seu papel no desenvolvimento de sociedades científicas e médicas no Brasil. Descrevemos suas contribuições desde sua tese de doutorado, em 1891, até a sua atuação durante 27 anos como diretor do Hospital Nacional de Alienados. Revisamos também o papel de Moreira na fundação de sociedades como a Academia Brasileira de Ciências, e da primeira revista brasileira dedicada à Neuropsiquiatria, concluindo que Moreira foi um dos mais importantes influenciadores para o desenvolvimento da Neurologia no Brasil. Além de sua ampla influência no campo da medicina, destacou-se como cidadão brasileiro, lutando contra teorias médicas racistas e xenófobas de seu tempo.

Palavras-chave: Juliano Moreira; História da Neurologia; Escola; Neuropsiquiatria.

Born in January 1872 in Salvador, Bahia, Juliano Moreira (Figure 1) is probably one of the most important influential figures for the modern schools of neurology and psychiatry in Brazil. He was the son of Galdina Joaquina do Amaral, enslaved at the residence of the Baron of Itapuã ${ }^{1,2}$. Moreira joined the Medical School of Bahia (FAMEB) in 1886 at the age of 14, two years prior to the abolition of slavery in Brazil. ${ }^{1}$ In 1890, he entered the clinic for dermatology, and for the

\footnotetext{
${ }^{1}$ Universidade Federal do Rio Grande do Sul, Faculdade de Medicina, Porto Alegre RS, Brazil.

${ }^{2}$ Universidade do Estado da Bahia, Faculdade de Medicina, Salvador BA, Brazil.

${ }^{3}$ Universidade Federal do Rio Grande do Sul, Faculdade de Medicina, Programa de Graduação em Medicina: Ciências Médicas, Porto Alegre RS, Brazil.

${ }^{4}$ Universidade Federal do Rio Grande do Sul, Faculdade de Medicina, Departamento de Medicina Interna, Porto Alegre RS, Brazil.

${ }^{5}$ Hospital de Clínicas de Porto Alegre, Serviço de Neurologia, Porto Alegre RS, Brazil.

${ }^{6}$ Hospital de Clínicas de Porto Alegre, Serviço de Genética Médica, Porto Alegre RS, Brazil.

Laura Motter Rosso (ID https://orcid.org/0000-0002-0304-5840; Ana Laura da Silva Brandi (D) https://orcid.org/0000-0003-3791-8897; Tais Cristóvão Martins Vieira (iD https://orcid.org/0000-0002-4358-4275; Edynara Lopes Rodrigues (DD https://orcid.org/0000-0003-4371-7055; Caroline da Silva Caminha (D) https:// orcid.org/0000-0001-5812-5453;Vinicius Farias Maurício (D) https://orcid.org/0000-0001-6287-6209; Liliane Touguinha (D) https://orcid.org/0000-0003-

2247-7179; Samuel Masao Suwa (iD) https://orcid.org/0000-0001-5550-5960; Ingrid Lorena da Silva Gomes (iD) https://orcid.org/0000-0001-6093-7557;Jonas Alex Morales Saute (iD https://orcid.org/0000-0003-1141-6573
}

Correspondence:Jonas Alex Morales Saute; Email: jsaute@hcpa.edu.br.

Conflict of interest: There is no conflict of interest to declare.

Authors' contribution: LMR, ALSB, TCMV: Drafting of First Version and Review and Critique; ELR, CSC, VFM, LT, SMS, ILSG: Drafting and Review and Critique of the article; JAMS: Conception, Writing of the First Draft and Review and Critique.

Received on October 20, 2020; Received in its final form on January 07, 2021; Accepted on January $13,2021$. 
study of syphilis which profoundly influenced his future medical interests. He graduated the following year at the age of 19 , with a thesis on syphilis, refuting climate and racial factors as determinants of disease severity ${ }^{3,4}$.

The advances in Moreira's learning regarding mental illness resulted in his appointment as assistant chair of Clinical Psychiatric and Nervous Diseases. In 1896, Moreira competed for a position as substitute lecturer in the Nervous and Mental Illness Department of FAMEB. Perhaps the best way to elucidate the situation Moreira faced would be to quote the man himself: "I intend to conquer the seat of substitute for the chair which is why, recognizing myself devoid of the external gifts that attract the favors of chance, I will never be at ease during the exciting and sometimes spectacular procedures of a tender" ${ }^{1,5}$. At the age of 24 , not only was Moreira approved for the position, but he secured first place, receiving the maximum score from the judges. In 1903, he took charge of the National Hospice for the Insane (NHI) in Rio de Janeiro, which he directed until 19302,6.

Moreira is well recognized within the field of psychiatry in Brazil; however, his influence in modern Neurology is little discussed. Hence, our aim is to highlight Moreira's importance in the field of Neurology and his role in the development of scientific and medical societies in the country.

Moreira first demonstrated his inclination towards Neuropsychiatry in his doctoral thesis "Etiology of Early

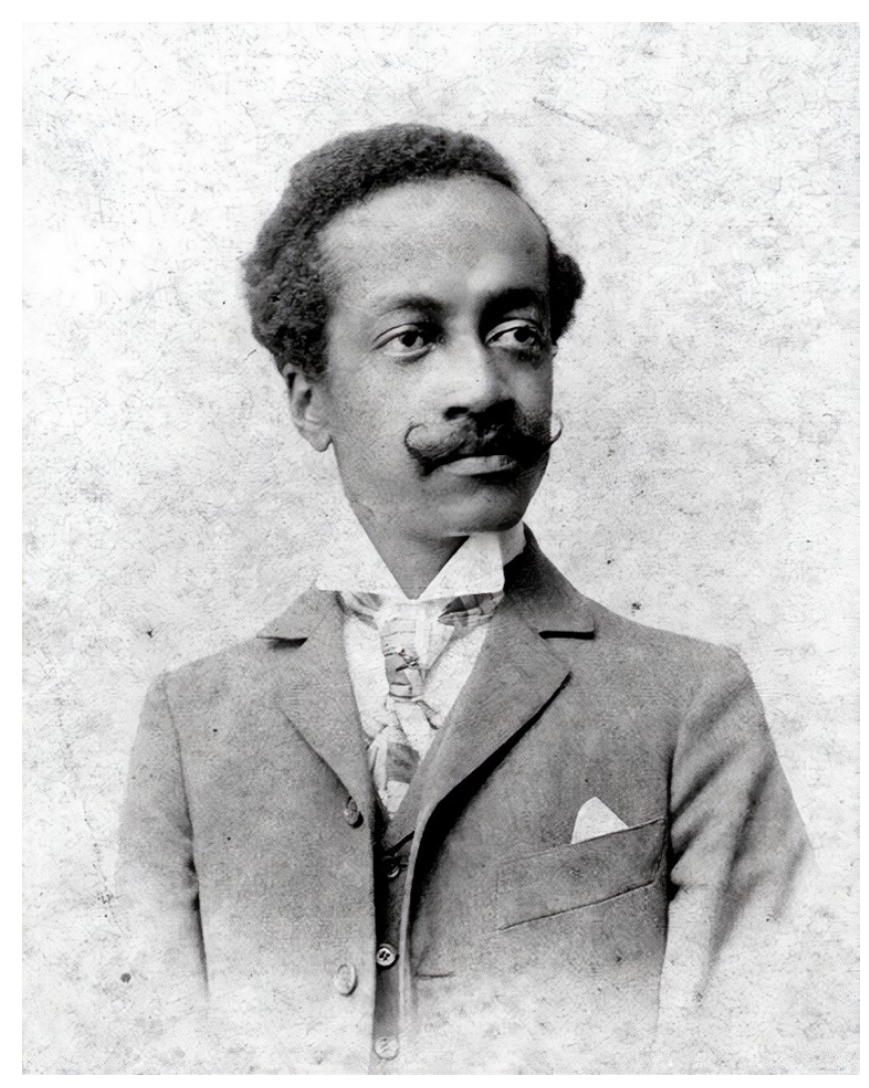

Source: Memorial Professor Juliano Moreira, Salvador, Bahia.

Figure 1. Juliano Moreira, the young neuropsychiatrist from Bahia.
Malignant Syphilis" ${ }^{3}$. In this work, Moreira identified a gap in the study of syphilis related to the causes that made the disease more severe in some patients, and refuted the widespread theory that syphilis was more prone to transmission and malignancy in the tropics due to climate and racial factors ${ }^{6}$. On his 1896 thesis for the substitute lecturer position entitled "Arsenic Dyskinesia", Moreira described the neurological manifestations of arsenic poisoning ${ }^{5}$.

Moreira also contributed with his writings and role at Gazeta Médica da Bahia (GMB), one of Brazil’s first scientific medical journals. From 1893, he published several articles on neurological consequences of syphilis and other nervous diseases $^{7}$. Moreira became editor of GMB in 1896 and editor-inchief in $1901^{7}$.

From 1903 until 1930, Moreira was the director of the $\mathrm{NHI}$, considered as the place where the practice of neurology began in Brazil ${ }^{2,6,8}$. During this period, the NHI underwent a series of renovations with the creation of new pavilions. Of note, Antônio Austregésilo, the regarded precursor of modern Brazilian neurology, was appointed in 1904 as the person in charge of one NHI pavilion?.

Another of Moreira's important contributions was the creation of the journal "Arquivos Brasileiros de Psiquiatria, Neurologia e Ciências Afins" in 1905; the first Brazilian publication specializing in Neuropsychiatry. Later, the journal changed its name to "Arquivos Brasileiros de Psiquiatria, Neurologia e Medicina Legal" following the foundation of the Brazilian Society of Neurology, Psychiatry, and Forensic Medicine in 1907 of which Moreira was the director until $1933^{10}$, and to "Arquivos Brasileiros de Neuriatria e Psiquiatria" in $1917^{11}$ which during five decades had wide-ranging influences on Brazilian Neurology.

Moreira was one of the founders of the International League Against Epilepsy in Budapest in $1909^{12}$, and was elected full member of the National Academy of Medicine of Brazil in 1903, acting as its vice-president from 1922-1923, and 1925-1933'. In May 1916, Moreira participated in the foundation of the Brazilian Academy of Sciences (ABC) and in 1917 he became its vice-president until 1926 when he became president (1926-1929). Moreira received Albert Einstein in Brazil in 1925, taking lunch with him during a visit to the NHI. Einstein, who was implacable in his diary notes, was very impressed by Moreira (Figure 2) ${ }^{1}$. For a detailed description of Moreira's contributions, see Supplementary file.

Despite all his medical contributions, Moreira struggled to be accepted as a black authority in a racist society in a time just 10 years after the abolition of black slavery in Brazil. In his doctoral thesis, Moreira rebutted the concept of race hierarchy and that native and black people were negative factors of miscegenation ${ }^{4}$, openly criticizing implicit racist theses on the inferiority of black people as being more vulnerable and severely affected by the disease $\mathrm{e}^{4}$.

Some authors consider that the neuropsychiatric scientific movement was initiated in Brazil by Moreira, since 


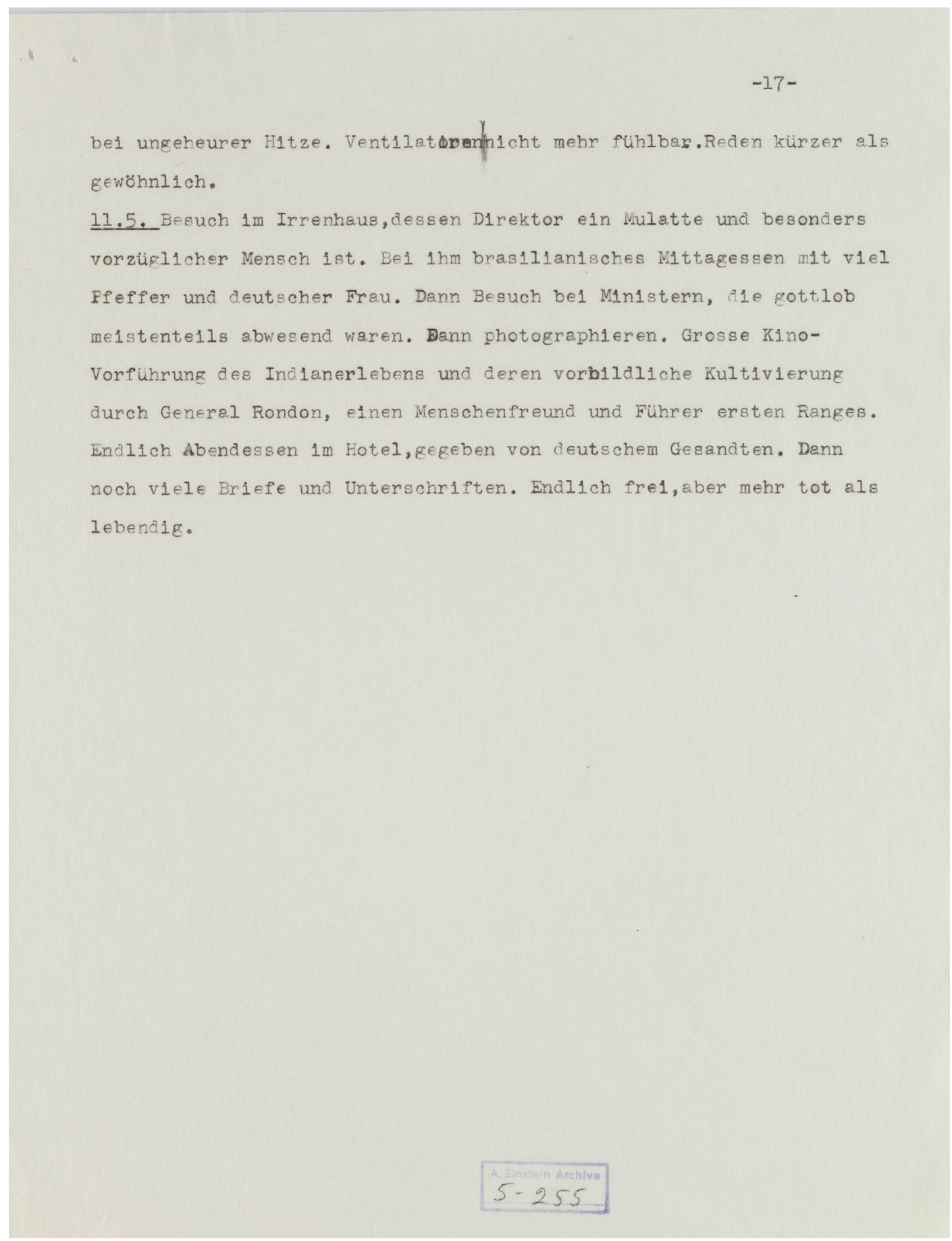

"Visit to the hospice whose director is a mulatto and a particularly virtuous person. With him, Brazilian lunch with lots of pepper and a German woman. Then, visit to ministers, thank God that most of them were absent.... We present the English translation of Einstein's diary entry regarding the meeting with Moreira on May 11, 1925.

Source: ()The Hebrew University of Jerusalem, Israel. Digital image photographed by Ardon Bar Hama.

The authors own the right to reproduce this material in the context of the present publication.

Figure 2. Excerpt from Albert Einstein's South America travel diary.

before him, miscegenation and heredity were considered to be the primary sources of most mental illness ${ }^{13}$. Moreira scientifically refuted xenophobic theories which stated that some mental and infectious diseases were climate-related, attempting to use those pathologies to prove a somewhat biological inferiority of non-white people ${ }^{14}$.

\section{FINAL REMARKS}

Moreira greatly influenced psychiatry and neurology in Brazil. Of note, Antônio Austregésilo worked under the direction of Moreira at NHI, participating in societies, academies and journals alongside him. Therefore, if not the founder of 
scientific neuropsychiatry, he is certainly one of the most important influential figures for the establishment and development of Clinical Psychiatry and Neurology in Brazil.

We conclude by quoting this great black Brazilian's first speech as a substitute lecturer at the age of 24, when Moreira said, "In days of more light and humanity, the external fog will no longer come to the line of account." We hope these days of more light might come soon.

\section{ACKNOWLEDGMENTS}

First, we have to thank professor Ronaldo Ribeiro Jacobina for his kind and careful reading of this manuscript, providing important insights to the authors, and for the inspiration to write this historical note, greatly based on readings of Jacobina's works on Moreira's life. We also thanks professor Maria Luiza Saraiva-Pereira and professor Alan Alves Brito for the counseling in the proper usage of terms to tackle systemic racism in science in the final version of this manuscript. We should mention that the conception of this article could be seen as an example of serendipity. During a mentorship program in the beginning of the COVID-19 pandemic, a group of medical students and a lecturer of the medical school of
Universidade Federal do Rio Grande do Sul, who coincidentally is a neurologist, were developing a storytelling activity about eminent Brazilian scientists from the past. During the activity, we "discovered" Juliano Moreira as a very important Brazilian scientist in ABC files (as we have discussed in the paper, Moreira was one of the founders and former president of this important scientific academy), and we were surprised about his contributions to the field of neuropsychiatry and neurology, and by the fact that none of us from a University in southern Brazil had ever heard about him and his role in neurology. Thereafter, our interest in Moreira's work rose with time while reading his works and works about him. We discussed our idea for writing this paper with Ingrid Lorena da Silva Gomes, a young physician recently graduated from Universidade do Estado da Bahia, who was familiar with Moreira's biography, and she joined us in the journey that culminated in the current paper.

\section{SUPPLEMENTARY MATERIAL}

The following material is available online for this article: S1. Search strategy for the historical note.

\section{REFERENCES}

1. Jacobina RR. Juliano Moreira da Bahia para o Mundo - a formação baiana do intelectual de múltiplos talentos (1872-1902). Salvador: EDUFBA; 2019. 323p.

2. Nardi AE, Carta MG, Shorter E. The remarkable Juliano Moreira (1872-1933): an Afro-Brazilian psychiatrist, scientist, and humanist in an environment of slavery and racism. Braz J Psychiatry. $2020 \mathrm{Jun}$ 12;43(3):237-9. https://doi.org/10.1590/1516-4446-2020-1097

3. Moreira J. Etiologia da Syphilis maligna precoce [Tese]. [Salvador]: Universidade Federal da Bahia, Faculdade de Medicina da Bahia; 1891.

4. Jacobina RR. Nem clima Nem Raça: A visão médico-social do acadêmico Juliano Moreira sobre a "Sífilis Maligna Precoce". Rev. Baiana de Saúde Pública. 2014 abr/jun;38(2):432-65. https://doi. org/10.22278/2318-2660.2014.v38.n2.a603

5. Moreira J. Dyskinesias arsenicaes: nova contribuição e estado actual da questão. [Tese de Concurso para o lugar de Lente Substituto da $12^{a}$ seção]. [Salvador]: Universidade Federal da Bahia, Faculdade de Medicina e Farmácia da Bahia; 1896.

6. Oda AMGR, Piccinini W. Dos males que acompanham o progresso do Brasil: a psiquiatria comparada de Juliano Moreira e colaboradores. Rev Latinoam Psicopatol Fundam. 2005 out./dez.;8(4):788-93.

7. Jacobina RR, Gelman, EA. Juliano Moreira e a Gazeta Médica da Bahia. Hist Cienc Saude Manguinhos. 2008 out./dez.;15(4):1077-97. https://doi.org/10.1590/S0104-59702008000400011

8. Meira AT, Betini BG, Cardoso F, Gomes MM, Barbosa EG, do Prado RCP, Teive HAG. First stages towards the establishment of Brazilian neurology faculties. Arq Neuropsiquiatr. 2019 Dec;77(12): 888-95. https://doi.org/10.1590/0004-282X20190147

9. Gomes MM, Cavalcanti MT. National hospice for the insane and the Brazilian Neurology in the beginning of the 20th century. Arq Neurosiquiatr. 2012 Oct;70(10):823-5. https://doi.org/10.1590/ S0004-282X2012001000013

10. Facchinetti C, de Muñoz PFN. Emil Kraepelin na ciência psiquiátrica do Rio de Janeiro, 1903-1933. Hist Cienc Saude Manguinhos. 2013 Mar; 20(1):239-62. https://doi.org/10.1590/S010459702013000100013

11. Facchinetti C, Ribeiro A, Chagas DC, Reis CS. No labirinto das fontes do Hospício Nacional de Alienados. Hist Cienc Saude Manguinhos. 2010;17(Suppl 2):733-68. https://doi.org/10.1590/S010459702010000600031

12. Shorvon S, Weiss G. International League Against Epilepsy - the first period:1909-1952. In: Shorvon S, Avanzini G, Meinardi H, Reynolds E, Weiss G, Engle J, Moshe S, Wolf P. International League Against Epilepsy: 1909 - 2009 A Centenary History. Wiley-Blackwell; 2009; 330 p. Limited edition

13. Portocarrero V. Arquivos da loucura: Juliano Moreira e a descontinuidade histórica da psiquiatria. Rio de Janeiro: Editora Fiocruz; 2002.152p. Available from: https://static.scielo.org/ scielobooks/p26q6/pdf/portocarrero-9788575413883.pdf

14. Moreira J, Peixoto A. Mental illnesses in tropical climates (1906). Int Rev Psychiatry. 2017 Jun;29(3):216-24. https://doi.org/10.1080/0954 0261.2017 .1285967 